\title{
Nutritional and anti-nutritional composition of monkey orange (Strychnos innocua Del) fruit seeds grown in Zuru, Nigeria
}

\author{
${ }^{1}$ Abdulmumin U., ${ }^{2}$ Umar K.J., ${ }^{1}$ Muhammad M. U., ${ }^{1 *}$ Abubakar L. \\ ${ }^{1}$ Department of Chemistry, Shehu Shagari College of Education, Sokoto \\ ${ }^{2}$ Department of Pure and Applied Chemistry, Federal University Birnin Kebbi \\ ${ }^{*}$ Corresponding Author's Email: lawaligada@gmail.com
}

\begin{abstract}
The Strychnos innocua (monkey orange) fruits were randomly collected from various locations in Zuru town of Kebbi State, Nigeria. The seeds of mature fruits were separated manually from the pulp and analysed for proximate, minerals, anti-nutritional compositions and physico-chemical analysis. The results showed that, the seed on dry weight basis (DW) contained crude protein $(9.36 \pm 0.29 \%)$, crude lipid $(25.0 \pm 0.82 \%)$, ash $(6.0 \pm$ $0.14 \%)$, available carbohydrates $(56.31 \pm 0.50 \%)$ and calorific value $(487.67 \pm 67.55 \mathrm{kcal} / 100 \mathrm{~g})$. The mineral elements $(\mathrm{mg} / 100 \mathrm{~g} \mathrm{DW})$ analysed showed that, the seed is rich in potassium (383.33 \pm 12.47$)$, sodium $(203.33 \pm 20.55)$, magnesium $(23.67 \pm 1.25)$, iron $(5.97 \pm 0.05)$, zinc $(21.47 \pm 0.05)$, and manganese $(3.67 \pm 0.05)$. Results of anti-nutritional analysis in the samples indicates high content of total oxalate $(26.25 \pm 5.30 \mathrm{mg} / 100 \mathrm{gDW})$ and phytic acid $(858.95 \pm 13.14 \mathrm{mg} / 100 \mathrm{gDW})$ respectively. With corresponding low concentration of cyanogenic glycosides, nitrate and saponins. Prediction of minerals bioavailability indicated that calcium and iron are not bioavailable due to oxalate and phytate content of the fruit. The oil had Saponification, lodine, acid and Peroxide value of $151.20 \pm 0.16 \mathrm{mgKOH} / \mathrm{g}$ oil, $14.53 \pm 0.06 \mathrm{~g} / 100 \mathrm{~g}$, $14.55 \pm 0.26 \mathrm{mgKOH} / \mathrm{g}$ oil and $8.06 \pm 0.49 \mathrm{meq} / \mathrm{kg}$ oil respectively.
\end{abstract}

Keywords: Strychnos innocua, Seeds, Nutrition, Anti-nutritional factors, Minerals, physico-chemical, Proximate composition.

\section{INTRODUCTION}

In most developing countries the food situation is worsening owing to increasing population, high prices of available staples and restrictions on import of food (Chadha, 2001; Roy, 2001). This causes high incidence of hunger and malnutrition, a situation in which children and women, especially pregnant and lactating women are most vulnerable (Coulyer et al., 1988; Pelletier, 1994). Today plant food is now viewed not only as the source of nutrients for performing basic nutritional role but also as a powerful medicine (Sood et al., 2010). Nigeria has abundant edible vegetables growing wild (Oguntona, 1998), which if properly utilised could supplement conventional food items. Consequently, the need to search for more edible wild plants in Nigerian with hope of using them to ease the malnutrition problems highlighted.

Strychnos innocua Del. (Monkey orange), belongs to the family Loganiaceae, a genus of Strychnos, commonly called 'Kokiyar Biri' in Hausa. It is a small, straightstemmed tree 3-14 m height, with a smooth, green or yellowish-white, powdery bark. Leaves are simple, alternate, leathery and elliptic in appearance. It flowers are greenish-white or yellowish and up to $8 \mathrm{~mm}$ long (Hutchinson, 1973; Orwa et al., 2009). Fruits are globose up to $6-10 \mathrm{~cm}$ in diameter, with a hard rind, bluish-green when young, yellowish or orange when ripe, with a thick woody shell, containing many seeds embedded in a yellowish pulp. Seeds are yellowish-white, tetrahedral, stony hard, 1.5-1.8 cm in diameter (Hutchinson, 1973; Orwa et al., 2009).

S. innocua tree occurs in savannah forests all over tropical Africa, in open woodland and rocky hills. The tree is found in Angola, Cameroon, Ethiopia, Ghana, Kenya, Nigeria, Senegal, Tanzania and Zimbabwe (Orwa et al., 2009).

Information on the nutritional contents of S. innocua 
fruit is not well known to the people eating it in the northern part of Nigeria. The aim of this work was to evaluate the nutritional and anti-nutritional compositions and physico-chemical analysis of $S$. innocua fruit seed with hope the information would be of use to those concerned with plant food for human nutrition.

\section{MATERIALS AND METHODS}

\section{Samples collection and preparation}

The matured fruits of $S$. innocua were randomly collected from different branches of ten trees from various locations in Zuru, Kebbi State, Nigeria. The fruit was authenticated at the Herbarium of the Department of Biological Sciences, Usmanu Danfodiyo University, Sokoto, Nigeria.

At the laboratory, the fruits were broken with a knife and the content oven dried at $70 \mathrm{oC}$ for $24 \mathrm{~h}$. The seeds were removed from the dried pulp manually by picking with hand. The seeds was crushed to powder using pestle and mortar. The powdered sample was used for the analyses, other than moisture content for which fresh samples were used.

\section{Proximate analysis}

The recommended methods of the Association of Official Analytical Chemists, AOAC (1990) were used for the determinations of moisture, ash, crude lipid, crude fibre and crude protein content. Available carbohydrate was estimated (by difference) using method described by James (1995). Calorific value (in $\mathrm{kcal} / 100 \mathrm{~g}$ ) was estimated by multiplying the percentages of crude protein, crude lipid and available carbohydrate by factors of 4,9 and 4 respectively and the product summed up (James, 1995).

\section{Mineral analysis}

\section{Sample digestion}

The sample $(0.5 \mathrm{~g}$ each) was put into Kjeldahl digestion flask to which $24 \mathrm{~cm} 3$ of a mixture of concentrated nitric acid (HNO3), conc. H2SO4 and 60\% HClO4 (9:2:1v/v) was added. The flask was allowed to stand over-night to prevent excess foaming (Sahrawat et al., 2002). The flask was put on a heating block and digested to a clear solution, cooled and the content filtered into a $50 \mathrm{~cm} 3$ volumetric flask. The solution was then diluted to the volume with distilled water. Blank solution was prepared in similar manner without sample being added. The solution was used for the mineral analysis.

The mineral contents (calcium, magnesium, iron, zinc, copper, manganese, lead, chromium, cobalt and cadmium) were analysed using AAS. Sodium and potassium were analysed using atomic emission spectrometry and phosphorus was determined by colorimetry using Vanadomolybdate (blue) method (AOAC, 1990).

\section{Anti-nutritional analysis}

The method reported by Krishna and Ranjhan (1980) was used for the determination of total oxalates. The method described by IITA (1988) was adopted in the determination of nitrate. The method reported by Ola and Obah (2000) was used for the determination of phytate. Hydrogen cyanide (HCN) was determined using AOAC, 1990 method. The method described by El-Olemy et al. (1994) was used for the determination of saponin content.

\section{Statistical analysis}

Data generated in triplicates were expressed as mean \pm standard deviation using SPSS version 16 statistical packages.

\section{RESULTS AND DISCUSSION}

The results of the proximate composition of $\mathrm{S}$. innocua fruit seeds investigated were shown in Table 1. The moisture content of the seed is $5.67 \pm 0.47 \%$, which is low when compared with $10 \%$ for Ceiba pentandra seeds Hassan et al. (2006). The value reported is comparable to $5.3 \pm 0.06 \%$ for Pentaclethra marcrophylla seed (Odoemelam, 2005). The low moisture content indicates that the seed have good storage quality with minimal fungal or microbial attack (Hassan et al., 2008).

The ash content of $S$. innocua fruit seed is $6.0 \pm$ $0.14 \%$ which is comparable with the seed of Ceiba pentandra $(5.00 \pm 0.35 \%)$ as reported by Hassan et al., 2006 , but less than $4.68 \pm 0.45 \%$ as reported for Parkia biglobosa seeds (Hassan et al., 2004a). Ash content of the sample gives an idea about the mineral content of the food material; which speed up metabolic processes and improve growth and development (Bello et al., 2008). This implies that, the seed has higher minerals contents.

The crude protein content of seed is $9.36 \pm 0.29 \%$. The value obtained is comparable to $9.19 \pm 0.62 \%$ for 
058 Afr. J. Food Sci. Technol.

Table 1.Proximate Compositions of Monkey orange fruit seeds $(\mathrm{g} / 100 \mathrm{~g})$ dry weight (DW).

\begin{tabular}{lc}
\hline Parameter & Seeds \\
\hline Moisture* & $5.67 \pm 0.47$ \\
Ash & $6.0 \pm 0.14$ \\
Crude Protein & $9.36 \pm 0.29$ \\
Crude Lipid & $25.0 \pm 0.82$ \\
Crude Fibre & $3.33 \pm 0.62$ \\
Available Carbohydrate & $56.31 \pm 0.50$ \\
Calorific Value (kcal/ $100 \mathrm{~g})$ & $487.67 \pm 6.55$ \\
\hline
\end{tabular}

The data are Mean \pm standard deviation of three replicates determinations * Wet weight

Table 2. Minerals Composition of Monkey orange seeds (mg/100g DW).

\begin{tabular}{lr}
\hline Mineral Element & \multicolumn{1}{c}{ Seeds } \\
\hline $\mathrm{K}$ & $383.33 \pm 12.47$ \\
$\mathrm{Na}$ & $203.33 \pm 20.55$ \\
$\mathrm{Ca}$ & $4.67 \pm 0.47$ \\
$\mathrm{Mg}$ & $23.67 \pm 1.25$ \\
$\mathrm{Zn}$ & $21.47 \pm 0.05$ \\
$\mathrm{Fe}$ & $5.97 \pm 0.05$ \\
$\mathrm{Cu}$ & $2.23 \pm 0.09$ \\
$\mathrm{Mn}$ & $3.67 \pm 0.05$ \\
$\mathrm{P}$ & $2.10 \pm 0.00$ \\
$\mathrm{~Pb}$ & $0.30 \pm 0.00$ \\
$\mathrm{Cr}$ & $0.40 \pm 0.00$ \\
$\mathrm{Co}$ & $1.07 \pm 0.05$ \\
$\mathrm{Cd}$ & $3.47 \pm 0.05$ \\
\hline
\end{tabular}

The data are Mean \pm standard deviation of three replicates.

Cola mikkenti seed (Bello et al., 2008) but lower than $29.53 \pm 0.35 \%$ DW for Silk cotton seeds (Hassan et al., 2006). The high crude protein content indicates that the seed is a potential source of protein supplements. Protein deficiency may cause growth retardation, muscle wasting, abnormal swelling of the belly and collection of fluids in the body (Zarkada et. al., 1997).

The crude lipid content of seed $(25.0 \pm 0.82 \%)$ is higher than $9.67 \pm 1.18 \%$ reported for Daniellia oliveri kernel seed (Hassan et al., 2008), but within the range of locust bean seed $(20.30 \pm \mathrm{g} / 100 \mathrm{~g})$ as reported by Ayodele et al. (2000). However, since the seeds are high in crude lipid, it could be a good source of edible vegetable oil if well harnessed, and could complement the conventional sources. Lipids provide the body with maximum energy; approximately twice that of protein and carbohydrate and facilitate intestinal absorption and transportation of solute vitamins-A, D, E and $\mathrm{K}$ (Dreon et al., 1990).

The crude fibre content for the seed is $3.33 \pm 0.62 \%$. The value reported is comparable to $4.03 \pm 0.01 \%$ obtained for Cola millenli seed by Bello et al. (2008), but lower than $15.00 \pm 2.05 \%$ DW reported in silk cotton seed (Hassan et al., 2006).

The available carbohydrate content of the seed is $56.31 \pm 0.50 \%$. The reported value is higher than $30.11 \pm 0.33 \%$ reported for Jatropha curcas seeds (AbouArab and Abu-Salem, 2010). The major function of carbohydrate is to provide the body with energy. Thus, this can probably be the reason for the high calorific value of the seeds $(487.67 \pm 6.55 \mathrm{kcal} / 100 \mathrm{~g})$.

Table 2, shows the minerals composition of the seed of monkey orange, the prevailing elements are potassium, sodium, manganese, iron, copper and zinc 
Abdulmumin et al. 059

Table 3. Anti - Nutritional Composition of Monkey orange seeds (mg/100g DW).

\begin{tabular}{ll}
\hline Ant-nutritional Factor & Seeds \\
& \\
\hline Cyanogenic glycoside & $0.96 \pm 0.02$ \\
Nitrate & $0.39 \pm 0.04$ \\
Oxalate & $26.25 \pm 5.30$ \\
Phytate & $858.95 \pm 13.14$ \\
Saponin & $3.20 \pm 0.40$ \\
\hline The data are Mean + standard deviation of three replicates.
\end{tabular}

The data are Mean \pm standard deviation of three replicates.

and calcium. Potassium concentration of the seed $(383.33 \pm 12.47 \mathrm{mg} / 100 \mathrm{~g})$ is higher compared to 357.14 $\mathrm{mg} / 100 \mathrm{~g}$ obtained for Annona muricata seeds (Kimbonguila et al., 2010) and within the range of 1930 $4776.90 \mathrm{mg} / \mathrm{kg}$ reported for some lesser known Nigerian fruits seed (Bello et al., 2008). Potassium is an essential nutrient and has an important role in the synthesis of amino acids and proteins (Kimbonguila et al., 2010). On the other hand, sodium content of the seeds (203.33 $\mathrm{mg} / 100 \mathrm{~g}$ ) is higher than $17.35 \pm 42.45 \mathrm{mg} / 100 \mathrm{~g}$ ) reported for Annona muricata seeds (Kimbonguila et al., 2010) but within the range of 790.15 to $1834.16 \mathrm{mg} / \mathrm{kg}$ reported for some lesser known Nigerian fruits, seeds (Bello et al., 2008). Calcium, magnesium and phosphorus concentrations $(\mathrm{mg} / 100 \mathrm{~g} \mathrm{DW})$ of the $S$. innocua seeds are $4.67 \pm 0.47,23.67 \pm 1.25$ and $2.10 \pm 0.0$ respectively. Calcium and phosphorus are essential in formation of development of bones (Donsunmu, 1997), blood clothing, muscles contraction and in certain enzymes in metabolic processes (Atasie et al., 2009). Manganese content of the sample is desirable in the body as it supports the immune system, regulates blood sugar levels and is involved in the production of energy and cell. It works with vitamin $\mathrm{K}$ to support blood clothing, and also helps to control the effect of stress (Anhawange, 2004). Birth defects can possibly result when a mother does not get enough of this important element (Anhawange, 2004; Abitogun et al., 2010). Recommended dietary allowance for manganese is $2-5 \mathrm{mg}$ (NRC, 1989; Hassan et al., 2006). The value for the seed $(3.67 \pm 0.05 \mathrm{mg} / 100 \mathrm{~g})$ could be a good source of manganese. Iron is an important element in the diet of pregnant women, nursing mothers and infants to prevent aneaemia (Oluyemi et al., 2006). The recommended daily allowance (RDA) for men is $7 \mathrm{mg} /$ day and 12-16 mg/day for pregnant women NHMRC (1991) and Abitogun et al. (2010). Iron concentration in the seed is $5.97 \pm 0.05 \mathrm{mg} / 100 \mathrm{~g}$. The elements lead, chromium, cobalt and cadmium are detected. Cobalt is essential trace element by virture of its function as component of vitamin $\mathrm{B}_{12}$ (cyanocobaltamin), and it is the vitamin $B_{12}$ in foods not the element cobalt that is essential (Hassan et al., 2006). This indicates that $S$. innocua fruit seed could be a good source of vitamin $B_{12}$.
The lead provision of tolerable weekly intake (PTWI) is $0.214 \mathrm{mg} / 100 \mathrm{~g}$ for $60 \mathrm{~kg}$ person (Lobet et al., 2003). Abolaji et al., (2007) reported that, lead is a highly toxic minerals element even at low concentration, for that consumption of the fruit seed should be with caution in other not to exceed the PTWI. Chromium in trivalent state is an essential trace element that potentiates insulin action and influences carbohydrate, lipid and protein metabolism (Duran et al., 2007). The maximum acceptable concentration of cadmium in plant food is 0.8 $\mathrm{mg} / 100 \mathrm{~g}$ (WHO, 1996). It is non-essential toxic element and interferes with the metabolism of some metals such as calcium, zinc and iron.

Table 3, shows the anti-nutritional factors of $S$. innocua. The cyanogenic glycoside (hydrocyanic acid) contents obtained for the seeds is high compared to 0.5 $\mathrm{mg} / 100 \mathrm{~g}$ in Hasta la pasta seeds kernel reported by Hassan et al. (2009), but lower when compared to the toxic level $(35 \mathrm{mg} / 100 \mathrm{~g})$ reported by Isong et al. (1999) and $20 \mathrm{mg} \mathrm{HCN}$, equivalent $\mathrm{kg}^{-1}$ sample is recommended by standard organization of Nigeria (Edijala et al., 1999). It was reported by Hassan et al. (2011) that, only plants with more than $200 \mathrm{mg}$ of $\mathrm{HCN}$ equivalent per $100 \mathrm{mg}$ fresh weight are considered dangerous. The nitrate content of the seed $(0.39 \pm 0.04 \mathrm{mg} / 100 \mathrm{~g})$ is lower than $13.50 \mathrm{mg} / 100 \mathrm{~g}$ reported for Hasta la pasta seeds (Hassan et al., 2009). The values observed are low compared to the recommended daily intake level of $3.7 \mathrm{mg} / \mathrm{kg}$ body weight equivalent to $220 \mathrm{mg}$ for $60 \mathrm{~kg}$ person (Hassan et al., 2011). However, studies have indicated that nitrates generally cause methaemoglobinaemia in young infants, but not in adults. Nitrate when reduced to nitrite it plays an important role in the body as it provides host defence against numerous micro-orgamisms (Hassan et al., 2011). The oxalate content in seed is $26.25 \pm 5.30$ $\mathrm{mg} / 100 \mathrm{~g}$. The value obtained for the seed is high compared to $9.45 \mathrm{mg} / 100 \mathrm{~g}$ reported by Hassan et al. (2009) for Hasta la pasta seed. The oxalate content observed is lower than the established toxic level of $2-$ $5 \mathrm{~g}$ (Birgitta and Caroline, 2000). Bello et al. (2008) reported that, the possibility of oxalate poisoning in Nigeria from intake of local fruits and vegetables is as remote as in other parts of the world. Oxalate can bind to 
060 Afr. J. Food Sci. Technol.

Table 4. Anti-nutrients to Nutrients Ration.

\begin{tabular}{|c|c|c|}
\hline Anti-nutrients to Nutrients Ratio & Seeds & Critical level $^{\star}$ \\
\hline [Oxalate] / [Ca] & 2.50 & 2.5 \\
\hline [Oxalate] / [Ca + Mg] & $2.64 \times 10^{-5}$ & 2.5 \\
\hline [Ca] [Phytate] / [Zn] & $4.60 \times 10^{-4}$ & 0.5 \\
\hline [Phytate] / [Ca] & 11.15 & 0.2 \\
\hline [Phytate] / [Fe] & 12.21 & 0.4 \\
\hline [Phytate] / [Zn] & 3.94 & 10 \\
\hline
\end{tabular}

source: Hassan et al., 2011

Table 5. Physico-chemical analysis Content of $S$. innocua oil.

\begin{tabular}{ll}
\hline Parameter & Concentration \\
\hline Specific gravity at $25^{\circ} \mathrm{C}$ & $0.65 \pm 0.04$ \\
Refractive index at $25^{\circ} \mathrm{C}$ & $0.67 \pm 0.08$ \\
$\mathrm{pH}$ & 6.30 \\
Saponification value $(\mathrm{mgKOH} / \mathrm{g}$ oil) & $151.20 \pm 0.16$ \\
lodine value $(\mathrm{g} / 100 \mathrm{~g})$ & $14.53 \pm 0.06$ \\
Peroxide value $(\mathrm{meq} / \mathrm{kg}$ oil) & $8.06 \pm 0.49$ \\
Acid value $(\mathrm{mgKOH} / \mathrm{g}$ oil) & $14.55 \pm 0.26$ \\
\hline
\end{tabular}

calcium present in food thereby rendering calcium unavailable for normal physiological and biochemical role such as the maintenance of strong teeth, cofactor in enzymatic reaction, nerve impulse transmission and as clothing factor in blood (Ladeji, 2007). The calcium oxalate, which is insoluble salt, may also precipitate around the soft tissues such as the kidney, causing kidney stone (Umar et al., 2007). Loss of calcium leads to degeneration of bones, teeth and impairment of blood clothing process (Badifu and Oke, 1992). The phytate (phytic acid) content in the seed is $858.95 \pm 13.14 \mathrm{mg} / 100 \mathrm{~g}$. The phytate value of $S$. innocua seeds is high compared to $51.05 \pm 16.14 \mathrm{mg} / 100 \mathrm{~g}$ reported by Hassan et al. (2008) for Daniellia oliveri seeds kernel, $73.0 \mathrm{mg} / 100 \mathrm{~g}$ in the seeds of Baobab (Chadare et al., 2009) and $320 \mathrm{mg} / 100 \mathrm{~g}$ in the of Zizyphus sonsrensis (Marcelino et al., 2005). Phytate is known to decrease the bioavailability of minerals, such as calcium, magnesium, iron and zinc (Hassan et al., 2011). It is also affects protein and starch solubility, digestion and absorption in the body (Hassan et al., 2011). The Saponins content in seed is $3.20 \pm 0.40 \mathrm{mg} / 100 \mathrm{~g}$. The values obtained are higher than the values reported by Adepoju, (2009) for Spondias mombin (1.06 $0.01 \mathrm{mg} / 100 \mathrm{~g})$; Dialium guineense $(0.20 \pm 0.02 \mathrm{mg} / 100 \mathrm{~g})$ and Mordii whytii $(1.82 \pm 0.08 \mathrm{mg} / 100 \mathrm{~g})$ fruits. The value obtained is lower than the values reported by Rathod and Valvi (2011) for Ziziphus rugosa $(31.7 \mathrm{mg} / 100 \mathrm{~g})$; Meyna laxiflora $(53.37 \mathrm{mg} / 100 \mathrm{~g})$ and Glycosmis pentaphylla $(38.57 \mathrm{mg} / 100 \mathrm{~g})$. High Saponin level has been associated with gastroenteritis manifested by diarrhea and dysentery
(Awe and Sodipi, 2001). Saponin reduced body cholesterol by preventing its reabsorption and cholesterol in the protozoan cell membrane thereby causing it to lyses (Umar et al., 2007).

Table 4 shows the anti-nutrients to nutrients molar ratio. To predict the effect of oxalate on the bioavailability of $\mathrm{Ca}$ and $\mathrm{Mg}$, the oxalate to nutrients ratios were calculated. The calculated molar ratios of [oxalate] / [Ca] is exactly the same with the critical level of 2.5 and the value for [oxalate] / [Ca $+\mathrm{Mg}$ ] is above the critical level of 2.5 known to impair the availability of the mineral. These indicate poor bioavailability of $\mathrm{Ca}$ and $\mathrm{Mg}$ due to oxalate.

To predict the effect of phytate on the bioavailability of $\mathrm{Ca}, \mathrm{Fe}$, and $\mathrm{Zn}$, phytate to nutrients ratios were calculated. The calculated molar ratios of [Ca] [Phytate] / [Zn] and [Phytate] / [Zn] are below the critical level of 0.5 , and 10 respectively (Hassan et al., 2011), but the calculated molar ratios of [Phytate] / [Ca] and [Phytate] / [Fe] are above the molar ratios of 0.2 and 0.4 respectively and this indicate poor bioavailability of Calcium and iron (Hassan et al., 2008).

Table 5 shows the physicochemical analysis of $S$. innocua fruit seed oil. The specific gravity of the oil of $S$. innocua seeds is $0.65 \pm 0.04$. The value obtained herein is low compared to 0.94 reported for baobab (Adansonia digitata) seed oil by Odetokun (1996), 0.92 reported for in $S$. birrea seed oil by Mariod et al. (1992), 0.91 recorded in Cananium album seed oil as reported by Zhiyong (2006) and specific gravity at any given temperature compared to water at a specific temperature increases as 
the degree of unsaturation increases (Rudan and Kloufutar, 1999).

The refractive index value of the oil is $0.67 \pm 0.08$, the value reported herein is low compared to 1.47 for baobab (Adansonia digitata) seed oil reported by Odetokun (1996), that of $S$. birrea seed oil (1.46) reported by Mariod et al. (1992) and 1.47 for Cananium album seed oil as reported by Zhiyong (2006). The refractive index of oil is an important parameter used in grading oil, and also detecting the degree of adultration (Chopra and Kanwar, 1999).

The saponification value of the oil is $151.20 \pm 0.16$. The value obtained herein is higher than $145.0 \pm 01.4$ observed in Blighia sapida (Sapindaceae) seed oil reported by Se'bastien et al. (2009). Also, the value reported in this study is low compared to $192.68 \mathrm{mgKOH} / \mathrm{g}$ observed in baobab seed oil as reported by Odetokun (1996) and $196.36 \mathrm{mgKOH} / \mathrm{g}$ observed in $S$. birrea seed oil reported by Mariod et al. (1992). The saponification value of the oil is inversely related to the average molecular weight of fatty acids in the oil fractions (Abayeh et al., 1998), this shows that, the oil contain low molecular weight fatty acids. The high saponification value of the oil is an indication that the oil contains high concentration of unsaturated fatty acids and could be used in the manufacture of soap, hair shampoo and so on.

The acid value of the seed oil obtained is $14.55 \pm$ $0.26 \mathrm{mgKOH} / \mathrm{g}$ of oil. The value obtained is high compared to $7.79 \mathrm{mgKOH} / \mathrm{g}$ of oil as reported for in baobab seed oil by Odetokun (1996) and $0.25 \mathrm{mgKOH} / \mathrm{g}$ of oil reported for in $S$. birrea seed oil (Ighodalo and Caterine, 1991). The value obtained is higher than the maximum acceptable value of $4.00 \mathrm{mgKOH} / \mathrm{g}$ of oil recommended by the Codex Alimenterius Commission for groundnuts (Abayeh et al., 1998). The high acid value of the oil could be an indication that, the oil is not edible, but rather advantageous in making soap (Awoyale et al., 1987).

The peroxide value of the oil is $8.06 \pm 0.49 \mathrm{meq} / \mathrm{kg}$ of oil. This value recorded is high compared to $5.14 \mathrm{meq} / \mathrm{kg}$ of oil in baobab seed oil, and $3.50 \mathrm{meq} / \mathrm{kg}$ of oil in Canarium album seed oil as reported by Odetokun (1996); Zhiyong (2006). However, the value obtained herein is low when compared to $25.00 \mathrm{meq} / \mathrm{kg}$ oil in $S$. birrea seed oil as reported by Mariod et al. (1992) and $20.00 \mathrm{meq} / \mathrm{kg}$ reported for castor oil by Ayedon et al., 2006. Also, the value is lower than $10-20 \mathrm{meq} / \mathrm{kg}$ maximum accepted values for groundnuts and olive oils (Abayeh et al., 1998). The peroxide value is an indication of the amount of hydroxides present in oil, as a result of lipid oxidation, and is a measure of its quality (Bell and Gillatt, 2004)
The iodine value of the oil reported is $48.43 \pm$ $0.06 \mathrm{~g} / 100 \mathrm{~g}$ of oil. The value obtained is low compared to $64.29 \mathrm{~g} / 100 \mathrm{~g}$ reported for in $S$. birrea seed oil, $82.41 \mathrm{~g} / 100 \mathrm{~g}$ reported for in baobab seed oil and $84.60 \mathrm{~g} / 100 \mathrm{~g}$ reported for in Canarium album seed oil as reported by Mariod et al. (1992); Odetokun (1996); Zhiyong (2006) respectively.

lodine value is a measure of degree of unsaturation of a fat or oil, and a Pure glyceryl triolcate has iodine value of $87.62 \mathrm{~g} / 100 \mathrm{~g}$, most edible oils have iodine values within this region (O'brian, 2004). The low iodine value obtained for $\mathrm{S}$. innocua seeds oil was an indication that the seeds crude lipid molecule may likely contain high amount of saturated fatty acids.

\section{CONCLUSION}

From the results it can be concluded that, monkey orange (S. innocua) fruit seeds can be considered a good source of protein, lipid, carbohydrates; mineral elements such as potassium, sodium, magnesium, zinc and calcium and. The fruit seeds contains anti-nutrition oxalate and phytates at a level that can reduce $\mathrm{Ca}, \mathrm{Mg}$ and $\mathrm{Fe}$ availability.

\section{REFERENCES}

Abitogun AS, Borokini FB, Ashogbon AO(2010). Nutritional and Chemical Composition of Ripe and Unripe Vitex glandifolia. J. Res. in National Development, 8(1): 1 - 8.

Abolaji OA, Adebayo AH, Odesanmi OS(2007). Nutritional Qualities of Three Medicinal Plant Parts (Xylopia aethiopica,Blighia sapida and Parinari polyandra) Commonly Used by Pregnant Women in the Western Part of Nigeria. Pakistan Journal of Nutrition, 6 (6): 665668.

Abou-Arab AA, Abu-Salem FM(2010). Nutritional Quality of Jatropha curcas Seeds and Effect of Some Physical and Chemical Treatments on their Anti-nutrional Factors. African J. Food Science, 4(3): $93-103$.

Adepoju OT(2009). Proximate Composition and Micronutrient Potentials of Three Locally Available Wild Fruits in Nigeria. African J. Agric. Res., 4(9):887-892.

Anhwange BA, Ajibola VO, Oniye SJ(2004). Chemical Studies of the Seeds of Moringa oleifera (Lam) and Deuterium microcarpum (Guill and Sperr). Journal of Biological Science, 4(6): 711-715.

AOAC (1990). Official Methods of Analysis, $14^{\text {th }}$ edition, Association of Official Analytical Chemists. Washington DC.

Atasie VN, Akinhanmi TF, Ojiodu CC(2009). Proximate Analysis and Physico-Chemical Properties of Groundnut (Srachis hypogaea L.). Pakistan J. of Nutrition, 8(2): $194-197$.

Awe SI, Sodipo OA(2001). Purification of Saponins of Root of Blighia sapida. Nigerian J. Biochem. and Molecular Biol., 16(3): $201-204$.

Ayodele JT, Alao OA, Olagbemiro TO(2000). The Chemical Composition of Sterculia setigera. Tropical J. Animal Sci, 3(2): 6976.

Badifu GI, Oke EM(1992). Effect of Bleaching on Oxalate Hydrocyanic

Acids of four Leafy Vegetable. J. Agric. Sci. Technology, 1: 71- 75.

Bello MO, Falade OS, Adewusi SR, Olawore NO(2008). Studies on the Chemical Compositions and Anti-nutrients of Some 
Lesser Known Nigeria Fruits. African J. Biotechnol., 7(21): 3972-3979.

Birgitta G, Caroline G(2000). Exploiting the Potential of Indigenous Wild Food Plants in Southern Sudan. Proceeding of a workshop held in Lokichoggio, Kenya. Pp. $22-25$.

Chadare FJ, Linnemann AR, Hounhouigan JD, Nout MJR, Van Boekel MAJS(2009). Baobab Food Products: A Review on their Composition and Nutritional Value. Critical Reviews in Food Sci. and Nutrition, 49: $254-274$

Chadha KL (2001). Food, Nutrition and Environmental Security through Horticultural Crops. Indian Hort, 45(4): 1 -3.

Coulyer JB, Suliman GI, Omer MI, MacFarlane SB, Moody JB, Hendrickse $R G(1988)$. Protein-energy Malnutrition in Northern Sudan: Clinical Studies. European J. Clin.I and Nutrition, 42: 787796.

Diouf J(2002). The State of Food Insecurity in the World, Published by the Food and Agriculture Organisation of the United Nations, Viale delle Terme di Caracalla, 00100,Rome, Italy.

Dosunmu MI(1997). Chemical Composition of the Fruit of Tetrapleura tetreptera and the Physico-chemical Properties of its Oil. Global J.Pure and Applied Sciences, 3(1): $61-67$.

Dreon DM, Vranizan KM, Krauss RM, Austin MA, Wood PD(1990). The Effects of Polyunsaturated Fat and Monounsaturated Fat on Plasma, Lipoproteins. J. American Medical Association, 263: 2462.

Duran A, Tuzen M, Soylak M(2007). Trace Element Levels in Some dried Fruit sampled from Turkey. International J. Food Sci. and Nutrition, 18(2): $51-58$.

Edijala KJ, Okoh PN, Anigoro R(1999). Chemical Assay of Cyanide Level of short time Fermented Cassava Products in the Abaraka Area of Delta State, Nigeria. Food Chemistry, 64: 107-110.

El-Olemy MM, Al-Muhtadi FJ, Afifi AA(1994). Experimental Phytochemistry: A Laboratory Manual. King Saud University Press

Epidemiologic Evidence and Policy Implications. Nutrition Review, 52: $409-415$.

Food and Agricultural Organization (FAO) (1983). Food and FruitBearing Forest Species-Examples from East Africa. Forestry Paper 44/1, FAO, Rome. 47.

Hassan LG, Usman BB, Kamba AS, Hassan SW(2009). Protein and Amino Acid Composition of Hasta la pasta Spaghetti Squasch (Cucurbita pepo L.) Tropical and Subtropical Agrosystems, 10: $295-299$.

Hassan LG, Dangoggo SM, Umar KJ, Sa'idu I, Folorunsho FA(2008). Proximate, Minerals and Anti-nutritional Factors of Daniellia oliveri Seed Kernel. Chemclass J, 5: $31-36$

Hassan LG, Sokoto MA, Dangoggo SM, Ladan MJ(2006). Proximate, Amino Acids and Minerals Compositions of Silk Cotton Seeds (Ceiba pentandra L.). African J. Natural Sci., 9: 29 - 35.

Hassan LG, Umar KJ(2004a). Proximate and Mineral Compositions of Seed and Pulp of African Locusts Beans (Parkia biglobosa I.). Nigerian J. Basic and Applied Sci., 13: 15-27

Hassan LG, Umar KJ, Dangoggo SM, Maigandi AS (2011). Antinutrient Composition and Bioavailability Prediction as Exemplified byCalcium, Iron and Zinc in Melocia corchorifolia Leaves. Pakistan J. Nutrition, 10 (1): 23-28,

Hutchinson J(1973). The Families of Flowering Plants. Clarendon Press, Oxford: 461-468

Isong EU, Adewusi SAR, Nkanga EU, Umor EE, Offiong EE(1999). Nutritional Evaluation of some Legumes-based Dishes Comsumed in Saudi Arabia. Intl. J. Food Sci. and Nutrition, 49: 193 - 197.

James OS(1995). Analytical Chemistry of food. Chapman and Hill. London, Pp 64-65.

Kimbonguila A, Nzikou JM, Matos L, Loumouamou B, Ndangui $\mathrm{CB}(2010)$. Res. J. Environmental and Earth Sci., 2(1): 13-18

Krishna G, Ranjhan SK(1980). Laboratory Manual for Nutrition Res.

Vikas Publishing House PVT Ltd, Ghaziabad, U.P. (India). Pp.104.
Ladeji O, Akin CU, Umaru HA(2007). Level of Antinutritional Factors in Vegetables Commonly Eaten in Nigeria. African J. Natural Sci. 7: $71-73$.

Lobet JM, Falco G, Casas C, Teixido A, Domingo JL(2003). Concentration of Arsenic, Cadmium, Mercury and Lead in common Foods and Estimated Daily Intake by Children, Adoulescents, Adults and Seniors of Catalonia, Spain. J. Agriculrure and Food Chemistry, 51: $838-842$

Manganese and Copper in Plant Materials. Communication of Soil Sciences and Plant Analysis, 33(1\&2): 95 - 102.

Marcelino M, Samuel C, Irma L, Chamacho H, Antelmo R, Francisco $\mathrm{D}(2005)$. Physicochemical and Nutritional Characteristics of the Fruits of Zizyphus sonorencis. International Journal of Food Science and Nutrition. 56(8): 587 - 596.

National Health and Medical Research Council (NHMRC) (1991). Recommended Dietary intakes for use in Australia. Canberrra: Australian Government

National Research Council, NRC (1989). Recommended Dietary Allowances, National Academy Press, Washington DC

Odoemelam SA(2005). Proximate Composition and Selected Physicochemical Properties of the Seeds of African Oil Bean (Pentaclethra marcrophylla). Pakistan Journal of Nutrition, $4(6): 382-383$.

Oguntona T(1998). Leafy Vegetables. In: Osagie, A.U. and Eka, O.U. (1998). (Eds.). Nutritional quality of plant foods. Post Harvest research unit, University of Benin, Benin City.

Ola FL, Obah $\mathrm{G}(2000)$. Food value of two Nigerian Edible Mushrooms (Termitomyceles stratus and Termitomyceles robustus). The J.Technoscience, 4: 1-3.

Oluyemi EA, Akinlua AA, Adenuga AA, Adebayo MB(2006). Mineral Contents of Some Commonly Consumed Nigerian Foods. Science Focus, 11(1): 153 - 157.

Orwa C, Mutua A, Kindt R, Jamnadass R, Simons A(2009). Agroforestree Database:a tree reference and selection guide version 4.0 available at (http://www.worldagroforestry.org/af/ treedb2/) assess on 13 march 2012. Pelletier, D.L. (1994). The Potentiating Effects of Malnutrition on Child Mortality:

Rathod, V.S. and Valvi, S.R. (2011). Antinutritional Factors of Some Wild Edible Fruits from Kolhapur District. Recent Research in Science and Technology, 3(5): $68-72$.

Roy KS(2001). Food, Nutrition and Environmental Security through Strategic post Harvest Management of Fruits and Vegetables. Indian Hort, 45(4): 4 - 7.

Sahrawat KL, Kumar GR, Rao JL(2002). Evaluation of Triacid and dry Ashing Procedures for Determining Potassium, Calcium, Magnesium, Iron, Zinc,

Sartaj A(2001). Why 800 million people still hungry? Sustainable Food Security for all by 2020 , September $4-6$, Bonn Germany.

Sood P, Modgil R, Sood M(2010). Physic-chemical and nutritional evaluation of indigenous Wild fruit Kasmal, Berberis lyceum Royle. Indian Journal of Natural Products and Resources, 1(3): 362-366

Umar KJ, Hassan LG, Dangoggo SM, Ladan M(2007). Nutritional Compositions of Water Spinach (Ipomoea aquatic Forsk) Leaves. J. Applied Sci., 7(6): 803 - 809.

WHO (1996). Guideline for Drinking Water Quality. $2^{\text {nd }}$ Edition, Vol. 2. World Health Organisation, Geneva.

Zarkada CG, Voldeng HD, Vu UK(1997). Determination of the Protein Quality of three new Northern Adapted Cultivars or Common and Mico types Soya Beans by Amino Acids Analysis. J. for Agric. and Food Chem., 45: 1161-1168. 